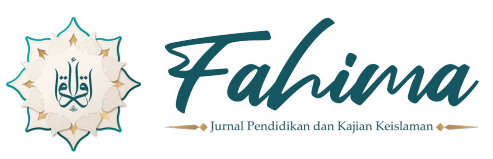

Fahima: Jurnal Pendidikan dan Kajian Keislaman

E-ISSN: 2808-4349 | P-ISSN: 2808-747X | Volume 1 No. 1 Januari 2022

\title{
PENGARUH VIRTUAL LEARNING PEMBELAJARAN JARAK JAUH GURU PENDIDIKAN AGAMA ISLAM DAN PARTISIPASI ORANG TUA TERHADAP HASIL BELAJAR \\ PAI
}

\author{
Heny Trikusuma Hidayati ${ }^{*}$, Ahmad Dardiri Hasyim² \\ ${ }_{1}^{1}$ SMAN 1 Karanganyar, Indonesia. \\ 2 Universitas Nahdlatul Ulama Surakarta, Indonesia. \\ *Surel Penulis Koresponden: henytrikusuma@gmail.com
}

\begin{tabular}{|l|l|l|l|}
\hline \multicolumn{4}{|c|}{ Riwayat Artikel } \\
\hline Dikirim: 4/11/2021 & Ditinjau: 4/11/2021 & Diperbaiki: 3/1/2022 & Diterima: 4/1/2022 \\
\hline
\end{tabular}

\begin{abstract}
Abstrak
Virtual learning memiliki peranan yang cukup penting terhadap pembelajaran pada masa pandemic sekarang ini. Dengan menerapkan pembelajaran virtual pada pembelajaran, diharapkan siswa bukan sekadar mendengarkan penjelasan materi dari guru, tetapi siswa akan belajar untuk berperan aktif dalam pembelajaran.

Penelitian ini bertujuan untuk mengetahui pengaruh virtual learning terhadap hasil belajar Pendidikan Agama Islam, pengarub partisipasi orang tua terhadap hasil belajar Pendidikan Agama Islam, serta pengaruh virtual learning dan partisipasi orang tua terhadap hasil belajar PAI SMPN 4 Karanganyar tabun ajaran 2020/2021. Adapun hipotesis yang diajukan adalab bahwa virtual learning dan parsipasi orang tua berpengaruh signifikan terhadap hasil belajar PAI siswa kelas VIII SMPN 4 Karnganyar tahun ajaran 2020/2021.

Jenis penelitian ini adalah deskriptif kuantitatif dengan metode pengumpulan data dilakukan melalui angket, observasi, wawancara dan dokumentasi. Subyek diambil siswa kelas VIII SMPN 4 Karanganyar dengan populasi 360 dan sampel 100 siswa. Analisis data dilakukan dengan cara analisa pendahuluan, uji hipotesis dan analisa lanjut.

Hasil penelitian menunjukkan babwa pengaruh virtual learning terhadap hasil belajar P AI masuk kategori baik, pengaruh partisipasi orang tua hasil belajar PAI berada pada kriteria baik, serta pengarub virtual learningdan dan partisipasi orang tua berpengaruh signifikean terhadap hasil belajar PAI siswa kelas VIII SMPN 4 Karanganyar Tahun Pelajaran 2020/2021 yang masuk dalam kategori baik.
\end{abstract}

Kata Kunci: Virtual learning, partisipasi orang tua, hasil belajar PAI 


\begin{abstract}
This study aims to determine the effect of virtual learning on Islamic Religious Education learning outcomes, the effect of parental participation on Islamic Religious Education learning outcomes, as well as the effect of virtual learning and parental participation on P AI learning outcomes at SMPN 4 Karanganyar academic year 2020/2021. The bypothesis proposed is that virtual learning and parental participation have a significant effect on PAI learning outcomes for class VIII SMPN 4 Karanganyar academic year 2020/2021.

This research is quantitative descriptive with data collection methods are questionnaires, observations, interviews and documentation. Subjects were taken by class VIII SMPN 4 Karanganyar with a population of 360 and a sample of 100 students. Data analysis used preliminary analysis, bypothesis testing and further analysis.

The results showed that the effect of virtual learning on PAI learning outcomes was in good category, the influence of parental participation on P AI learning outcomes was in good criteria, and the influence of virtual learning and parental participation had a significant effect on PAI learning outcomes for class VIII students of SMPN 4 Karanganyar academix year 2020/2021 which is in the good category.
\end{abstract}

Keywords: Virtual learning, parent participation, PAI learning outcomes

\title{
A. PENDAHULUAN
}

Perkembangan ilmu pendidikan dan teknologi telah berdampak pada perubahan kehidupan masyarakat, perkembangan tersebut telah merubah paradigma manusia dalam mencari dan mendapatkan informasi yang semakin mudahPerkembangan ilmu pendidikan dan teknologi telah berdampak pada perubahan kehidupan masyarakat, perkembangan tersebut telah merubah paradigma manusia dalam mencari dan mendapatkan informasi yang semakin mudah. Pekerjaan yang biasanya dilakukan secara manual kini bergeser pada mesin (Sofyana \& Rozaq, 2019). Hal ini menuntut manusia untuk berpikir lebih berinovasi dan maju dalam segala hal agar tidak ketinggalan. Salah satu bidang yang cukup signifikan dalam perkembangan IPTEK adalah pendidikan. Pendidikan adalah proses komunikasi dan informasi antara pendidik dan peserta didik, media berperan sebagai sarana penyampaian ide, gagasan, dan materi pendidikan.

Perkembangan teknologi pendidikan pada hakikatnya merupakan proses transfer informasi. Dimana informasi dapat diartikan sebagai objek abstrak yang dapat digunakan untuk mencapai tujuan positif atau negatif. Mempercepat atau memperlambat keputusan. Dengan demikian informasi memiliki kekuatan, baik konstruktif maupun destruktif, untuk menjadi simbol dan kebutuhan masyarakat modern (information society).

Teknologi informasi dapat diartikan sebagai teknologi elektronik yang mampu mendukung percepatan dan peningkatan kualitas informasi yaitu 
melalui internet, percepatan arus informasi tidak lagi dibatasi oleh ruang dan waktu. Internet merupakan salah satu sarana yang dapat digunakan untuk memajukan dan meningkatkan kualitas pendidikan. Internet adalah media baru dengan konten teknologi tinggi.

Penggunaan teknologi dan informasi dalam ilmu pengetahuan terhadap proses belajar yaitu guru selalu mengalami kesulitan dalam mengontrol situs situs yang dimiliki oleh siswa, baik saat belajar di dalam kelas dan di luar kelas, selain itu semakin individualis serta semakin jarang melakukan interaksi sosial langsung antar pribadi akan tetapi lebih banyak melalui media sosial yang diikuti oleh Email, Telegram, SMS, Facebook, Whatsapp, Line, Twitter, dan berbagai media sosial lainnya. Sehingga anak didik sering kali sulit konsentrasi pada materi pelajaran yang sedang dipelajari (Maunah, 2016).

Pendidikan diarahkan untuk mengubah nalar, mental dan sikap manusia yang umunya dari kondisi yang sebelumnya kurang baik menuju lebih baik. Pendidikan sangat penting bagi penganut seluruh umat Islam yaitu. Hal tersebut disebutkan dijelaskan di dalam Al-Qur'an dan hadis tentang perintah untuk mencari ilmu. Pendidikan dijelaskan di dalam al Quran adalah usaha untuk mengolah manusia menuju sebuah perubahan yang lebih baik dari waktu ke waktu.

Pendidikan Islam dilakukan dengan usaha dan didikan serta ajaran Islam melalui perbuatan, contoh dan suri teladan. Diajarkan dengan cara lemah lembut, bertatakrama terhadap siapapun, etika dalam bermasyarakat, ikhlas dalam membantu sesama, amanah dan menjaga kepercayaan orang lain, pengasih dan pemurah dengan yang lemah, jujur dan adil, menghormati adat istiadat siapapun umat dan golongannya. Dengan demikian mereka tertarik untuk mempelajari Pendidikan Agama Islam. Karena pendidikan berbasis rintisan melalui dunia pengajaran langsung lambat laun tergerus oleh perkembangan zaman, akhirnya banyak pendidik yang melakukan perbaikan kualitas pembelajaran dengan memperhatikan kemajuan zaman.

Tolok ukur keberhasilan suatu pembelajaran tergantung pada pencapaian tujuan kompetensi belajar siswa yang meliputi kompetensi kognitif, afektif, psikomotorik dan terwujudnya penerapan nilai baik dalam berpikir maupun bertindak. Memastikan bahwa semua siswa memiliki penguasaan kompetensi dalam suatu bahan ajar dan kemudian melanjutkan ke materi berikutnya adalah tujuan dari penguasaan pembelajaran. Ketuntasan belajar mengacu pada kompetensi yang dicapai dan didukung oleh indikator untuk mengukur tingkat pencapaiannya. Semua aspek ketuntasan belajar hanya dapat dicapai dengan kerjasama dan kerjasama antara dua pihak yaitu guru dan siswa. 
Pengajar agama Islam melaksanakan pendidikan kapan saja, dimana saja dengan siapa saja dalam setiap kesempatan yang ada, bahkan di jaman dahulu pembelajaran dapat di tepi sungai sambil menunggu perahu yang akan mengangkut barang keseberang, di padang rumput sambil mengembala ternak, di pasar sambil berjualan, dan saat ini biasa dilakukan di warung kopi, cave, restauran mall, hotel dan sebagainya. Pada waktu itulah pendidikan agama Islam diajarkan dan didikkan kepada mereka yang membutuhkan dengan cara yang mudah dengan demikian orang akan dapat pula menerima masukan dan mengamalkan ajaran yang diberikan.

Pendidikan Islam sebenarnya telah mengikuti berbagai perkembangan yang dapat diterima dan menjauhi segala hal yang dianggap merusak eksistensi nilai-nilai Islam. Pada abad ini penggunaan media komputer sebagai media pembelajaran pendidikan sudah merajalela, bahkan hampir setiap pelajar atau masyarakat umum perkotaan telah terbukti dapat menggunakan komputer, mereka selalu berteman dengan komputer di tempat-tempat yang unik, misalnya: hik, warnet dan lain-lain. Agar semua nilai nilai pendidikan agama Islam dapat dinilai positif sesuai perkembangan jaman dibutuhkan adaptasi yang efektif dan efesien dimanapun dan kapanpun.

Menciptakan proses pendidikan yang bermutu sangat diperlukan peran serta masyarakat, keluarga dan pemerintah, sesuai yang tercantum dalam Undang-Undang No. 20 Tahun 2003 Pasal 54 serta Hak dan Kewajiban Masyarakat pasal 8 yang berbunyi: "Peran serta masyarakat dalam pendidikan meliputi peran serta perseorangan, kelompok, keluarga, organisasi profesi, pengusaha, dan organisasi kemasyarakatan dalam penyelenggaraan dan pengendalian mutu pelayanan pendidikan." (Tim Sinar Grafika, 2008).

"Masyarakat berhak berperan serta dalam perencanaan, pelaksanaan, pengawasan, dan evaluasi program pendidikan." (Tim Sinar Grafika, 2008) Wujud kerja sama dan tanggung jawab yang baik oleh semua pihak adalah ikut berpartisipasi dalam pengelolaan pendidikan berupa pemikiran, pelaksana dan pengontrol jalanya proses pendidikan disemua jenjang pendidikan. Nantinya melalui peran serta masyarakat tersebut akan mewujudkan sistem pendidikan berkualitas bersesuai dengan kebutuhan dan keinginan masyarakat.

Pendidikan dan keluarga merupakan satu kesatuan kehidupan (sistem sosial), dan keluarga menyediakan situasi belajar. Sebagai unit kehidupan (sistem sosial) keluarga terdiri dari ayah, ibu, dan anak. Ikatan keluarga membantu anak mengembangkan sifat persahabatan, cinta, hubungan interpersonal, kerjasama, disiplin, perilaku yang baik, dan pengakuan otoritas.

Kurangnya akses ke teknologi atau konektivitas internet yang baik 
adalah Kendala untuk terus belajar, terutama bagi siswa dari keluarga kurang mampu. Cara untuk mengurangi resiko penyebaran virus COVID-19, ratusan perpustakaan telah ditutup sementara. Penerapan program belajar jarak jauh bagi siswa yang tidak memiliki akses internet, ini menjadi kesulitan tersendiri bagi mereka untuk mengikuti pembelajaran jarak jauh

\section{B. METODE PENELITIAN}

Jenis pendekatan penelitian ini adalah studi lapangan (deskriptif kuantitatif). Penelitian deskriptif kuantitatif untuk mengetahui gambaran pengaruh virtual learning pembelajaran jarak jauh guru PAI dan partisipasi orang tua terhadap hasil belajar PAI siswa SMP Negeri 4 Karanganyar. Metode pengambilan data menggunakan angket, wawancara dan observasi. Populasi penelitian 360 siswa dan diambil sampel 27,8 \% sehingga ada 100 siswa. Tempat penelitian adalah SMP Negeri 4 Karanganyar.

\section{HASIL DAN PEMBAHASAN}

\section{Virtual Learning, Partisipasi Orang Tua, dan Hasil belajar}

Virtual learning sering dikenal dengan pembelajaran jarak jauh. Ibrahim mengatakan pembelajaran jarak jauh (distance education) dan telah lama dikenal manusia sejak tahun 1870-an (Ibrahim, 2005). Pendidikan jarak jauh pada awalnya berupa korespondensi, obyek sasaran utamanya adalah orang dewasa. Awalnya proses pembelajaran menggunakan bahan cetak atau tertulis, dan distribusikan melalui jasa pos. Selanjutnya pembelajaran jarak jauh meningkat menggunakan media elektronik seperti radio dan televisi. Tahun 1990 pembelajaran jarak jauh mulai mengenal multimedia. Pembelajaran jarak jauh sekarang digunakan untuk peserta didik di jaman serba Online dan internet yang kemudian dikenal dengan adanya perkembangan virtual learning di sekolah karena jauh lebih efektf dan efesien.

Peserta didik dalam Pembelajaran Jarak Jauh (PJJ) belajar tepisah dengan pendidik. Sumber pembelajaran menggunakan internet sesuai dengan teknologi informasi dan komunikasi dengan bantuan media yang canggih. Sesuai dengan UU nomor 20 tahun 2003 pasal 1 ayat 15 yang isinya "Pendidikan jarak jauh adalah pendidikan yang perserta didiknya terpisah dari pendidik dan pembelajarannya menggunakan berbagai sumber belajar melalui teknologi komunikasi, informasi dan media lain."

Penerapan pembelajaran virtual meliputi, komponen siswa, guru, dan sumber belajar yang difasilitasi dengan TIK untuk mencapai tujuan belajar. Prinsip utama dalam pembelajaran virtual adalah kebebasan dan kolaborasi. 
Siswa memiliki tanggung jawab untuk menentukan materi, akses terhadap sumber belajar, waktu yang dimiliki, media yang akan digunakan, serta tempat dan langkah-langkah belajar yang dilakukan untuk mencapai tujuan pembelajaran. Kolaboratif dalam arti, untuk dapat melakukan tanggung jawab siswa tersebut untuk berinteraksi dengan siswa lain, guru atau tutor, dan sumber belajar lain yang tersedia. Virtual Learning dapat menjadikan kebebasan dan waktu yang diperlukan untuk pelaksanaan pendidikan akan dapat diatasi. Karena semua yang diperlukan akan tersedia secara online sehingga dapat diakses kapan saja.

Partisipasi adalah keterlibatan mental dan emosional seseorang dalam situasi kelompok yang mendorong mereka untuk mencapai tujuan kelompok dan bertanggung jawab atas kelompok. Partisipasi dapat diartikan sebagai keterlibatan mental dan emosional dalam situasi kelompok sehingga dapat dijadikan sebagai motivasi dalam mencapai tujuan organisasi. Selanjutnya partisipasi juga diartikan sebagai kesediaan untuk membantu mensukseskan setiap program sesuai dengan kemampuan masing-masing orang tanpa mengorbankan kepentingannya sendiri.

Partisipasi orang tua adalah keterlibatan nyata orang tua dalam suatu kegiatan. Partisipasi orang tua dapat berupa ide, kritik yang membangun, dukungan, dan pelaksanaan pendidikan. Orang tua memiliki peran yang sangat penting dalam pendidikan dan kemajuan sekolah. Bentuk partisipasi yang diberikan dapat berupa ide, tenaga, dan materi atau harta. Jadi partisipasi dapat digolongkan dalam beberapa bentuk, yaitu pikiran, keterampilan (berupa keterampilan tertentu yang dimiliki seseorang dan dapat diterapkan dalam suatu kegiatan), tenaga, harta benda, dan uang.

Partisipasi orang tua menjadi kunci utama dalam keberhasilan pelaksanaan virtual learning selama siswa di rumah. Dwiningrum berpendapat bahwa partisipasi merupakan keterlibatan mental dan emosi dari seseorang di dalam situasi tertentu yang mendorong orang lain mencapai pada tujuannya serta ikut bertanggungjawab (Dwiningrum, 2011). Partisipasi orang tua yang dapat diberikan untuk mendukung siswa dalam proses belajar, menurut Somawati, antara lain dalam bentuk: pengasuh/pendidik, pembimbing, motivator, dan juga sebagai fasilitator. Keempat bentuk partisipasi orang tua tersebut dapat menunjang keberhasilan pelaksanaan pembelajaran online di rumah serta hal baik lainnya yaitu siswa akan merasa semangat dalam belajar (Somawati dkk., 2020).

Hamalik berpendapat hasil belajar adalah sebagai terjadinya perubahan tingkah laku pada diri seseorang yang dapat diamati dan diukur bentuk 
pengetahuan, sikap dan keterampilan. Perubahan tersebut dapat diartikan sebagai terjadinya peningkatan dan pengembangan yang lebih baik dari sebelumnya dan yang tidak tahu menjadi tahu. Hasil belajar dapat diartikan sebagai hasil maksimum yang telah dicapai oleh seseorang siswa setelah mengalami proses belajar mengajar dalam mempelajari materi pelajaran tertentu. Hasil belajar tidak mutlak berupa nilai saja, akan tetapi dapat berupa perubahan, penalaran, kedisiplinan, keterampilan dan lain sebagainya yang menuju pada perubahan positif (Hamalik, 2013).

Pengertian hasil belajar merupakan proses untuk menentukan nilai belajar siswa melalui kegiatan penilaian atau pengukuran hasil belajar (Sudjana, 1996). Hasil belajar dapat memenui tujuan utamanya yaitu mengetahui tingkat keberhasilan yang dicapai oleh siswa setelah mengikuti suatu kegiatan pembelajaran, dimana tingkat keberhasilan tersebut kemudian ditandai dengan skala nilai berupa huruf atau kata atau simbol.

Hasil belajar menunjukkan kemampuan yang sebenarnya dari siswa yang telah mengalami proses transfer pengetahuan dari seseorang yang dapat dikatakan dewasa atau memiliki pengetahuan yang kurang. Sehingga dengan hasil belajar, masyarakat dapat mengetahui sejauh mana siswa dapat menangkap, memahami, menguasai materi pelajaran tertentu. Atas dasar itu, pendidik dapat menentukan strategi belajar mengajar yang lebih baik

\section{Temuan Penelitian}

Virtual learning memiliki banyak perbedaan dengan metode pembelajaran yang dilakukan secara tatap muka. Pada praktik pembelajaran virtual learning, guru lebih banyak memanfaatkan beberapa aplikasi pembelajaran berbasis online serta banyak memanfaatkan jaringan internet. Hasil pengamatan dan wawancara penulis dengan guru menunjukkan bahwa SMP Negeri 4 Karanganyar dalam pembelajaran menggunakan aplikasi Ukline, whats App dan google form . Ukline merupakan aplikasi resmi yang digunakan untuk SMP se kabupaten Karanganyar. Ada beberapa fitur yang bisa digunakan untuk pembelajaran virtual learning, antara lain penyampaian materi, modul dan bank soal.

Persiapan pembelajaran dimulai dengan persiapan perangkat pembelajaran dan semua dokumen pendukung. Pada awal semester, guru dibentuk dalam tim yang telah disesuaikan dengan kelas dan materi yang akan diajarkan. Kegiatan ini merupakan bagian dari rencana pembelajaran yang didalamnya terdapat kegiatan pembuatan alat pembelajaran, media, bahan ajar, serta berbagai instrumen tugas dan penilaian yang nantinya akan diberikan kepada siswa pada saat pembelajaran online. Persiapan belajar yang baik diharapkan dapat memberikan dampak positif terhadap hasil 
belajar siswa saat belajar online

Partisipasi orang tua memiliki pengaruh yang besar terhadap proses belajar anak dan prestasi belajar yang ingin dicapai. Sejumlah penelitian yang telah dilakukan menemukan hubungan antara partisipasi orang tua dalam pendidikan dengan prestasi anak. Kim menunjukkan bahwa ada hubungan yang signifikan antara partisipasi orang tua dan prestasi siswa di sekolah. Van Voorhis menyatakan bahwa siswa mencapai hasil yang lebih tinggi ketika orang tua mereka memberikan bantuan ketika mendapatkan pekerjaan rumah. Studi lain juga menemukan bahwa partisipasi orang tua di sekolah memiliki dampak langsung pada keberhasilan siswa.

Orang tua di SMP Negeri 4 Karanganyar dalam pembelajaran ada yang mendampingi dan ada beberapa hanya mengawasi saja. Keadaan mata pencaharian orang tua peserta didik di SMP Negeri 4 Karanganyar bermacam-macam. Kebanyakan dari mereka karyawan pabrik, buruh, pedagang dan petani. Sebagian ada yang merantau baik keluar kota, provinsi maupun ke luar negeri. Peserta didik ada yang tinggal dengan nenek atau kakeknya karena ditinggal orang tua yang sedang merantau. Kondisi demikian menyebabkan kurangnya dukungan orang tua terhadap kemajuan peserta didik. Berkurangnya perhatian dari orang tua inilah yang menyebabkan motivasi dan keikutsertaan dalam pembelajaran jarak jauh tidak optimal (Sutomo, komunikasi pribadi, 21 Juni 2021).

\section{Analisis Data dan Pembahasan}

Penelitian ini dilakukan di SMP Negeri 4 Karanganyar. Subyek penelitian ini adalah siswa kelas 8 Tahun Ajaran 2020/2021, yang berjumlah 356 orang, tapi diambil sampel 100 siswa. Hasil penelitian ini merupakan hasil studi lapangan (deskriptif kuantitatif) yang diambil dengan angket,wawancara dan dokumentasi. Dokumentasi digunakan untuk mengambil data hasil belajar siswa kelas 8 Tahun Ajaran 2020/2021 pada mata pelajaran Pendidikan Agama Islam semester genap, sedangkan kuesioner digunakan untuk mengukur persepsi siswa terhadap virtual learning PJJ guru PAI dan partisipasi orang tua terhadap hasil belajar PAI.

\section{Analisis Virtual Learning PJJ GPAI}

Variabel Virtual Learning PJJ GPAI diukur dengan 20 pertanyaan sehingga dapat diketahui nilai-nilai parameter sebagai berikut:

Skor minimum ideal $=20 \times 1=20$

Skor maksimum ideal $=20 \times 5=100$ 
Nilai rata-rata ideal $\quad=\frac{100+20}{2}=60$

Nilai standar deviasi ideal $\quad=\frac{100-20}{6}=13.3$

Berdasarkan data Virtual Learning PJJ GPAI menunjukkan bahwa skor total tertinggi yang dicapai adalah 98 dan skor total terendah adalah 55. Hal ini berarti skor maksimum yang terjadi pada Virtual Learning PJJ GPAI adalah 98 yang nilainya jauh diatas dari nilai rata-rata ideal, sehingga menunjukkan penilaian yang sangat baik, dan standar deviasi sebesar 10,424 berarti fluktuasi dari penilaian responden terhadap Virtual Learning PJJ GPAInya adalah $\pm 10,424$ dari 100 observasi yang diamati.

Tabel 1. Distribusi Frekuensi Skor virtual Leaning PJJ GPAI

\begin{tabular}{|c|c|c|c|}
\hline No & Interval Kelas & Frekuensi & Persentase \\
\hline 1 & $55-60$ & 4 & $4 \%$ \\
\hline 2 & $61-66$ & 6 & $6 \%$ \\
\hline 3 & $67-72$ & 15 & $15 \%$ \\
\hline 4 & $73-78$ & 14 & $14 \%$ \\
\hline 5 & $79-84$ & 22 & $22 \%$ \\
\hline 6 & $85-90$ & 22 & $22 \%$ \\
\hline 7 & $91-96$ & 10 & $10 \%$ \\
\hline 8 & $97-102$ & 7 & $7 \%$ \\
\hline \multicolumn{2}{|c|}{ Total } & 100 & $100 \%$ \\
\hline
\end{tabular}

Sumber: data primer yang diolah

Tabel diatas menunjukkan bahwa mayoritas skor jawaban responden pada interval antara $67-90$ yaitu sebesar $73 \%$. Tabel distribusi frekuensi skor variabel Virtual Learning PJJ GPAI di atas dapat digambarkan dalam histogram berikut ini:

\section{Virtual Learning PJJ GPAI}

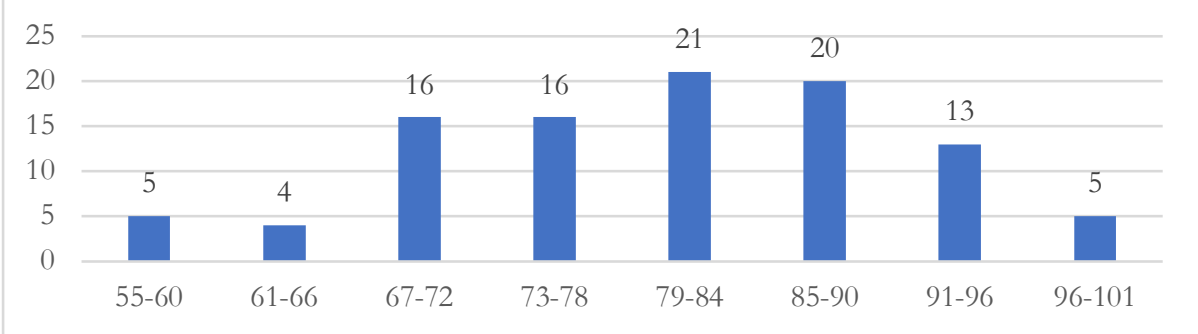

Gambar 1. Histogram Distribusi Frekuensi Variabel Virtual Learning PJJ GPAI 
Analisis Partisipasi Orang Tua

Variabel Partisipasi Orang Tua diukur dengan 20 pertanyaan sehingga dapat diketahui nilai-nilai parameter sebagai berikut:

Skor minimum ideal $=20 \times 1=20$

Skor maksimum ideal $=20 \times 5=100$

Nilai rata-rata ideal $=\frac{100+20}{2}=60$

Nilai standar deviasi ideal $\quad=\frac{100-20}{6}=13.3$

Tabel 2. Distribusi Frekuensi Skor Variabel Partisipasi Orang Tua

\begin{tabular}{|c|c|c|c|}
\hline No & Interval Kelas & Frekuensi & Persentase \\
\hline 1 & $57-62$ & 3 & $3 \%$ \\
\hline 2 & $63-68$ & 2 & $2 \%$ \\
\hline 3 & $69-74$ & 10 & $10 \%$ \\
\hline 4 & $75-80$ & 12 & $12 \%$ \\
\hline 5 & $81-86$ & 19 & $19 \%$ \\
\hline 6 & $87-92$ & 20 & $20 \%$ \\
\hline 7 & $93-98$ & 20 & $20 \%$ \\
\hline 8 & $99-104$ & 14 & $14 \%$ \\
\hline \multicolumn{2}{|r|}{ Total } & 100 & $100 \%$ \\
\hline
\end{tabular}

Sumber: data primer yang diolab

Tabel diatas menunjukkan bahwa mayoritas skor jawaban responden pada interval antara 81-98 yaitu sebesar 59\%. Tabel distribusi frekuensi skor variabel Partisipasi Orang Tua di atas, dapat digambarkan dalam histogram berikut ini:

\section{Partisipasi Orang Tua}

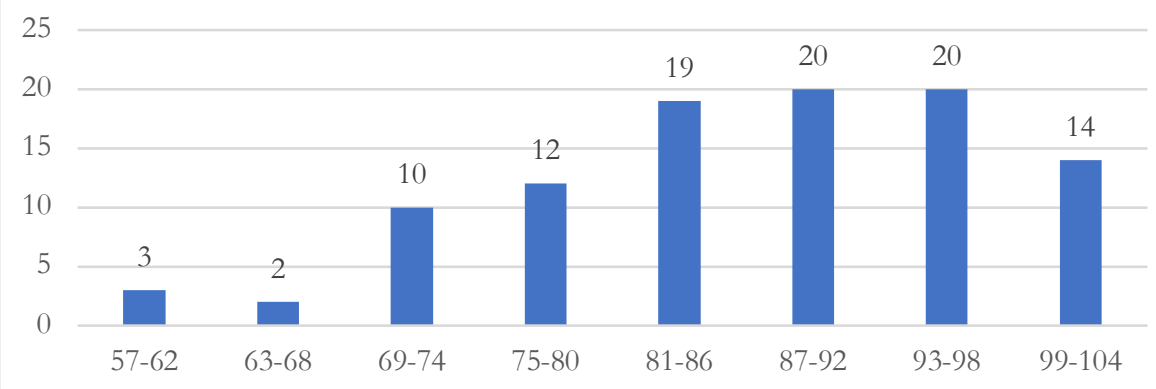

Gambar 2. Histogram Distribusi Frekuensi Variabel Partisipasi Orang Tua 
Analisis Pengaruh virtual learning PJJ GPAI dan partisipasi orang tua terbadap hasil belajar PAI siswa SMP Negeri 4 Karanganyar

Variabel Hasil Belajar PAI diambilkan dari nilai raport anak dengan nilai tertinggi 95 dan nilai terendah 76 sehingga dapat diketahui nilai-nilai parameter sebagai berikut :

Nilai Tertinggi $=95$

Nilai Terendah $=76$

Berdasarkan data Hasil Belajar PAI menunjukkan bahwa skor total tertinggi yang dicapai adalah 95 dan skor total terendah adalah 76 . Hal ini berarti skor maksimum yang terjadi pada Hasil Belajar PAI adalah 95 yang nilainya jauh di atas dari nilai rata-rata ideal, sehingga menunjukkan penilaian yang sangat baik, dan standar deviasi sebesar 3,982 berarti fluktuasi terhadap Hasil Belajar PAI adalah \pm 3,983 dari 100 responden yang diamati.

Distribusi frekuensi skor tercantum dalam tabel berikut:

Tabel 3. Distribusi Frekuensi Skor Variabel Hasil Belajar PAI

\begin{tabular}{|c|c|c|c|}
\hline No & Interval Kelas & Frekuensi & Persentase \\
\hline 1 & $76-78$ & 38 & $38 \%$ \\
\hline 2 & $79-81$ & 27 & $27 \%$ \\
\hline 3 & $82-84$ & 15 & $15 \%$ \\
\hline 4 & $85-87$ & 16 & $16 \%$ \\
\hline 5 & $88-90$ & 1 & $1 \%$ \\
\hline 6 & $91-93$ & 2 & $2 \%$ \\
\hline 7 & $94-98$ & 1 & $1 \%$ \\
\hline 8 & $99-101$ & 0 & $0 \%$ \\
\hline \multicolumn{2}{|c|}{ Total } & 100 & $100 \%$ \\
\hline
\end{tabular}

Sumber: data primer yang diolah

Tabel diatas menunjukkan bahwa mayoritas skor jawaban responden pada interval antara $76-81$ yaitu sebesar 65\%. Tabel distribusi frekuensi skor variabel Hasil Belajar PAI di atas, dapat digambarkan dalam Histogram berikut ini: 


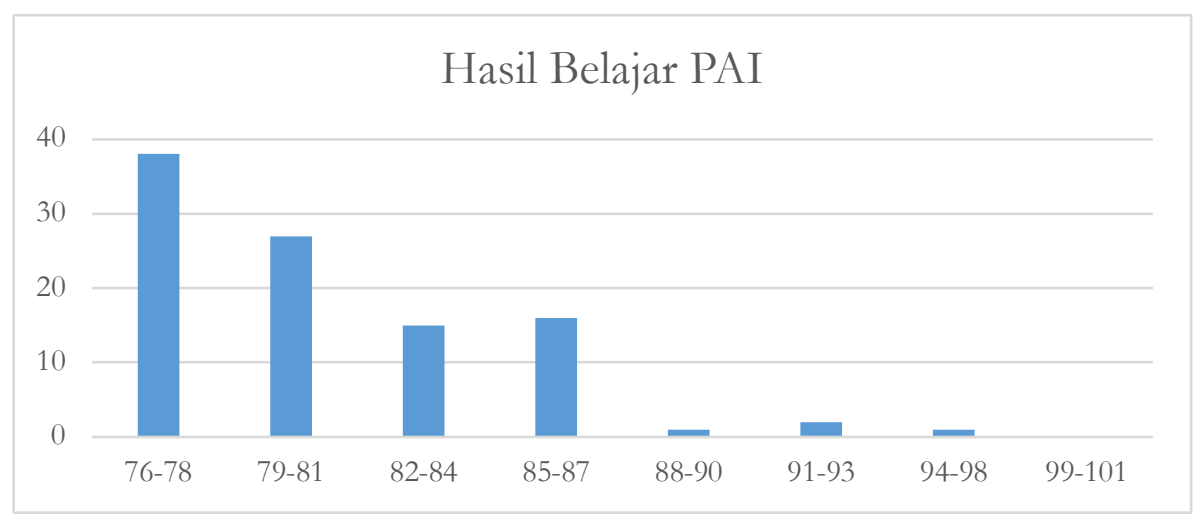

Gambar 3. Histogram Distribusi Frekuensi variabel Hasil Belajar PAI

\section{Uji Hipotesis}

Hipotesis merupakan jawaban sementara atas permasalahan yang dirumuskan. Oleh sebab itu, jawaban sementara ini harus diuji kebenarannya secara empiris. Pengujian hipotesis dalam penelitian ini dilakukan dengan menggunakan teknik regresi sederhana untuk hipotesis pertama, kedua, dan ketiga, sedangkan untuk hipotesis yang keempat menggunakan teknik regresi berganda. Penjelasan tentang hasil pengujian hipotesis ini adalah sebagai berikut:

a. Pengujian Hipotesis Pertama

Hipotesis pertama menyatakan bahwa "Virtual Learning PJJ GPAI berpengaruh positif terhadap Hasil Belajar PAI siswa SMP Negeri 4 Karanganyar tahun 2020/2021”. Untuk menguji hipotesis pertama ini digunakan analisis regresi linier sederhana.

Dengan bantuan seri program Statistik (SPSS) for windows 17 diperoleh rangkuman hasil analisis regresi linier sederhana seperti pada tabel sebagai berikut:

Tabel 4. Hasil Analisis Regresi Linier Sederhana (Virtual Learning PJJ GPAI)

\begin{tabular}{|c|c|c|c|c|c|c|}
\hline \multicolumn{7}{|c|}{ Coefficients $^{\mathrm{a}}$} \\
\hline & \multirow[t]{2}{*}{ Model } & \multicolumn{2}{|c|}{$\begin{array}{c}\text { Unstandardized } \\
\text { Coefficients }\end{array}$} & \multirow{2}{*}{$\begin{array}{c}\begin{array}{c}\text { Standardized } \\
\text { Coefficients }\end{array} \\
\text { Beta }\end{array}$} & \multirow[t]{2}{*}{$\mathrm{t}$} & \multirow[t]{2}{*}{ Sig. } \\
\hline & & $\mathrm{B}$ & Std. Error & & & \\
\hline \multirow{2}{*}{1} & (Constant) & 76,915 & 3,336 & & 23,058 & ,000 \\
\hline & Virtual Learning TOT & ,043 & 038 & 112 & 1,119 & 266 \\
\hline
\end{tabular}




\begin{tabular}{|c|c|c|c|c|c|c|c|c|c|}
\hline \multicolumn{10}{|c|}{ Model Summary } \\
\hline \multirow[b]{2}{*}{ Model } & \multirow[b]{2}{*}{$\mathrm{R}$} & \multirow[b]{2}{*}{ R Square } & \multirow[b]{2}{*}{$\begin{array}{l}\text { Adjusted } \\
\text { R Square }\end{array}$} & \multirow[b]{2}{*}{$\begin{array}{l}\text { Std. Error of } \\
\text { the Estimate }\end{array}$} & \multicolumn{5}{|c|}{ Change Statistics } \\
\hline & & & & & $\begin{array}{l}\text { R Square } \\
\text { Change }\end{array}$ & $\begin{array}{c}\text { F } \\
\text { Change }\end{array}$ & df1 & df2 & $\begin{array}{c}\text { Sig. F } \\
\text { Change }\end{array}$ \\
\hline 1 & ,115a & 013 &,- 007 & 3,996 & 013 & ,655 & 2 & 97 & ,522 \\
\hline \multicolumn{10}{|c|}{ a. Predictors: (Constant), PartisipasiOrtuTOT, VirtualLearningTOT } \\
\hline
\end{tabular}

Sumber: Data primer diolah, 2021

Hasil analisis regresi linier sederhana seperti pada table di atas dapat ditulis persamaan regresi yaitu sebagai berikut :

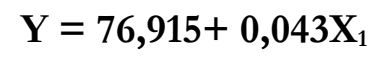

Nilai konstanta sebesar 76,915 hal ini berarti bahwa Hasil Belajar PAI akan sebesar 76,494 jika Virtual Learning PJJ GPAI sama dengan nol. Hal ini dapat dijelaskan bahwa Hasil Belajar PAI Siswa akan menurun jika tidak ada pembelajaran dengan Virtual Learning GPAI.

Variabel Virtual Learning PJJ GPAI (X1) mempunyai pengaruh positif terhadap Hasil Belajar PAI, dengan koefisien regresi sebesar 0,043 menunjukkan bahwa apabila Kecerdasan Emosional meningkat sebesar 1 persen maka Hasil Belajar PAI akan meningkat sebesar 0,043 persen dengan asumsi variabel bebas yang lain konstan. Nilai signifikan (sig) sebesar 0,000, nilai ini jauh lebih rendah dibandingkan dengan 0,05 maka pengaruh Virtual Learning PJJ GPAI terhadap Hasil Belajar PAI adalah signifikan.

Berdasarkan perhitungan SPSS, nilai thitung sebesar 0,791, sedangkan $\mathrm{p}$ value sebesar 0,000 , sehingga $\mathrm{p}$ value $<5 \%(0,000<0,05)$, artinya ada pengaruh signifikan variabel Virtual Learning PJJ GPAI terhadap Hasil Belajar PAI. Hasil ini menunjukkan bahwa semakin tinggi Virtual Learning PJJ GPAI maka Hasil Belajar PAI akan semakin baik, begitu pula sebaliknya.

Koefisien determinasi R2 sebesar 0,013 yang berarti 1,3\% variasi pada variabel dependen Hasil Belajar PAI dapat dijelaskan oleh variasi variabel independen Virtual Learning PJJ GPAI. Sedangkan sisanya 98,7\% dipengaruhi oleh variabel yang tidak dijelaskan dalam model tersebut.

Dengan demikian hipotesis pertama yang menyatakan "Virtual Learning PJJ GPAI berpengaruh positif terhadap Hasil Belajar PAI siswa SMP Negeri 4 Karanganyar tahun 2020/2021” diterima. 
b. Pengujian Hipotesis Kedua

Hipotesis kedua menyatakan bahwa "Patisipasi Orang Tua berpengaruh positif terhadap Hasil Belajar PAI siswa SMP Negeri 4 Karanganyar tahun 2020/2021”. Untuk menguji hipotesis kedua ini digunakan analisis regresi linier sederhana.

Dengan bantuan seri program Statistik (SPSS) for windows 7 diperoleh rangkuman hasil analisis regresi linier sederhana seperti pada tabel sebagai berikut:

Tabel 5. Hasil Analisis Regresi Linier Sederhana (Partisipasi Orang Tua PJJ GPAI)

\begin{tabular}{|c|c|c|c|c|c|c|}
\hline \multicolumn{7}{|c|}{ Coefficients $^{a}$} \\
\hline & \multirow[t]{2}{*}{ Model } & \multicolumn{2}{|c|}{$\begin{array}{c}\text { Unstandardized } \\
\text { Coefficients }\end{array}$} & \multirow{2}{*}{$\begin{array}{c}\text { Standardized } \\
\text { Coefficients }\end{array}$} & \multirow[t]{2}{*}{$\mathrm{t}$} & \multirow[t]{2}{*}{ Sig. } \\
\hline & & $\mathrm{B}$ & Std. Error & & & \\
\hline \multirow{2}{*}{1} & (Constant) & 77,972 & 3,185 & & 24,484 & ,000 \\
\hline & Partisipasi Ortu TOT & ,033 & 039 & 084 & ,838 & ,404 \\
\hline
\end{tabular}

\begin{tabular}{|c|c|c|c|c|c|c|c|c|c|}
\hline \multicolumn{10}{|c|}{ Model Summary } \\
\hline \multirow[b]{2}{*}{ Model } & \multirow[b]{2}{*}{$\mathrm{R}$} & \multirow{2}{*}{$\begin{array}{c}\mathrm{R} \\
\text { Square }\end{array}$} & \multirow{2}{*}{$\begin{array}{l}\text { Adjusted } \\
\text { R Square }\end{array}$} & \multirow{2}{*}{$\begin{array}{l}\text { Std. Error of the } \\
\text { Estimate }\end{array}$} & \multicolumn{5}{|c|}{ Change Statistics } \\
\hline & & & & & $\begin{array}{l}\text { R Square } \\
\text { Change }\end{array}$ & $\begin{array}{c}\text { F } \\
\text { Change }\end{array}$ & df1 & df2 & $\begin{array}{l}\text { Sig. F } \\
\text { Change }\end{array}$ \\
\hline 1 & ,084a & ,007 &,- 003 & 3,988 & ,007 & ,702 & 1 & 98 & ,404 \\
\hline
\end{tabular}

Sumber: Data primer diolah, 2021

Hasil analisis regresi linier sederhana seperti pada tabel di atas dapat ditulis persamaan regresi yaitu sebagai berikut :

$$
\mathbf{Y}=\mathbf{7 7 , 9 7 2}+\mathbf{0 , 0 3 3 \mathbf { X } _ { 2 }}
$$

Nilai konstanta sebesar 77,972 hal ini berarti bahwa Hasil Belajar PAI akan sebesar 77,972 jika Patisipasi Orang Tua sama dengan nol. Hal ini dapat dijelaskan bahwa Hasil Belajar PAI akan menurun jika tidak ada Partisipasi Orang Tua dalam Pembelajaran PJJ PAI.

Variabel Patisipasi Orang Tua $\left(\mathrm{X}_{2}\right)$ mempunyai pengaruh positif terhadap Hasil Belajar PAI, dengan koefisien regresi sebesar 0,033 menunjukkan bahwa apabila Partisipasi Orang Tua meningkat sebesar 1 persen maka Hasil Belajar PAI akan meningkat sebesar 0,33 persen dengan asumsi variabel bebas yang lain konstan. Nilai signifikan (sig) 
sebesar 0,000, nilai ini jauh lebih rendah dibandingkan dengan 0,05 maka pengaruh Patisipasi Orang Tua terhadap Hasil Belajar PAI adalah signifikan.

Berdasarkan perhitungan SPSS, nilai thitung sebesar 0,838 , sedangkan $\mathrm{p}$ value sebesar 0,000 , sehingga $\mathrm{p}$ value $<5 \%(0,000<0,05)$, artinya ada pengaruh signifikan variabel Patisipasi Orang Tua terhadap Hasil Belajar PAI. Hasil ini menunjukkan bahwa semakin tinggi Patisipasi Orang Tua maka Hasil Belajar PAI akan semakin baik, begitu pula sebaliknya.

Koefisien determinasi R2 sebesar 0,007 yang berarti 0,7\% variasi pada variabel dependen Hasil Belajar PAI dapat dijelaskan oleh variasi variabel independen Partisipasi Orang Tua, sedangkan sisanya 99,3\% dipengaruhi oleh variabel yang tidak dijelaskan dalam model tersebut.

Dengan demikian hipotesis kedua yang menyatakan "Patisipasi Orang Tua berpengaruh positif terhadap Hasil Belajar PAI siswa SMP Negeri 4 Karanganyar tahun 2020/2021” diterima.

c. Pengujian Hipotesis Ketiga dengan Regresi Berganda

Untuk mempermudah perhitungan regresi dari data yang cukup banyak maka dalam penelitian ini diselesaikan dengan bantuan perangkat lunak (software) komputer program SPSS 17. Hasil pengujian terhadap model regresi berganda terhadap variabel Virtual Learning PJJ GPAI (X1), dan Patisipasi Orang Tua (X2), yang mempengaruhi Hasil Belajar PAI (Y) siswa SMP Negeri 4 Karanganyar tahun 2020/2021, dapat dilihat dalam tabel 28 berikut:

Tabel 6. Hasil Analisis Regresi Linier Berganda

\begin{tabular}{|c|c|c|c|c|c|c|}
\hline \multicolumn{7}{|c|}{ Coefficients $^{a}$} \\
\hline & \multirow[t]{2}{*}{ Model } & \multicolumn{2}{|c|}{$\begin{array}{l}\text { Unstandardized } \\
\text { Coefficients }\end{array}$} & \multirow{2}{*}{$\begin{array}{c}\begin{array}{r}\text { Standardized } \\
\text { Coefficients }\end{array} \\
\text { Beta }\end{array}$} & \multirow[t]{2}{*}{$\mathrm{t}$} & \multirow[t]{2}{*}{ Sig. } \\
\hline & & B & Std. Error & & & \\
\hline \multirow{3}{*}{1} & (Constant) & 76,494 & 3,710 & & 20,619 & 000 \\
\hline & Virtual Learning TOT & ,036 & ,046 & ,095 & ,781 & 437 \\
\hline & Partisipasi Ortu TOT & ,013 & ,047 & ,032 & ,265 & ,792 \\
\hline
\end{tabular}


Fahima: Jumal Pendidikan dan Kajian Keislaman

E-ISSN: 2808-4349 | P-ISSN: 2808-747X | Volume 1 No. 1 Januari 2022

\begin{tabular}{|c|c|c|c|c|c|c|}
\hline \multicolumn{7}{|c|}{ Anova $^{\text {a }}$} \\
\hline \multicolumn{2}{|c|}{ Model } & Sum of Squares & Df & Mean Square & F & Sig. \\
\hline 1 & Regression & 20,911 & 2 & 10,455 &, 655 &, $522^{\mathrm{b}}$ \\
\cline { 2 - 7 } & Residual & 1548,649 & 97 & 15,965 & & \\
\cline { 2 - 8 } & Total & 1569,560 & 99 & & & \\
\hline \multicolumn{2}{|l|}{ a. Dependent Variable: HasilBelajarPAI } \\
\hline b. Predictors: (Constant), PartisipasiOrtuTOT, VirtualLearningTOT \\
\hline
\end{tabular}

\begin{tabular}{|c|c|c|c|c|c|c|c|c|c|}
\hline \multicolumn{2}{|c|}{ Model Summary } \\
\hline \multirow{2}{*}{ Model } & $\mathrm{R}$ & $\begin{array}{c}\mathrm{R} \\
\text { Square }\end{array}$ & $\begin{array}{c}\text { Adjusted } \\
\mathrm{R} \text { Square }\end{array}$ & $\begin{array}{c}\text { Std. Error of the } \\
\text { Estimate }\end{array}$ & $\begin{array}{c}\text { R Square } \\
\text { Change }\end{array}$ & $\begin{array}{c}\mathrm{F} \\
\text { Change }\end{array}$ & $\mathrm{df1}$ & $\mathrm{df2}$ & $\begin{array}{c}\text { Sig. F } \\
\text { Change }\end{array}$ \\
\hline 1 &, $115^{\mathrm{a}}$ &, 013 &,- 007 & 3,996 &, 013 &, 655 & 2 & 97 &, 522 \\
\hline \multicolumn{3}{|c|}{ a. Predictors: (Constant), PartisipasiOrtuTOT, VirtualLearningTOT } \\
\hline
\end{tabular}

Sumber: Data hasil regresi, 2013

Pada penelitian ini digunakan model persamaan regresi linear berganda sebagai berikut :

$$
\mathbf{Y}=\mathbf{a}+\mathrm{b}_{1} \mathbf{X}_{1}+\mathrm{b}_{2} \mathbf{X}_{2}
$$

Dengan memperhatikan model regresi dan hasil regresi linear berganda maka didapat persamaan faktor-faktor yang mempengaruhi Hasil Belajar PAI sebagai berikut :

$$
\mathrm{Y}=76,494+0,036 \mathrm{X}_{1}+\mathbf{0 , 0 1 3 \mathrm { X } _ { 2 }}
$$

Dari tabel 17 di atas di dapat F hitung sebesar 20,619 dengan taraf signifikansi 0,000. Hal ini menunjukkan bahwa probabilitas $<$ taraf signifikansi yang ditolerir $(0,000<0,05)$, maka Ha diterima dan menolak Ho. Ini menunjukkan bahwa terdapat pengaruh positif signifikan Virtual Learning PJJ GPAI, Partisipasi Orang Tua, secara bersama-sama terhadap Hasil Belajar PAI.

Kemudian untuk menunjukkan berapa persen pengaruh Virtual Learning PJJ GPAI, Partisipasi Orang Tua secara bersama-sama terhadap Hasil Belajar PAI digunakan koefisien determinasi. Dari tabel 17 di atas dapat diketahui koefisien determinasi $\left(R^{2}\right.$ square) sebesar 0,013, yang berarti 1,3\% variasi Hasil Belajar PAI dapat dijelaskan oleh kedua variabel bebas yang terdiri dari Virtual Learning PJJ GPAI, dan Partisipasi Orang Tua, sedangkan sisanya 98,7\% variasi Hasil Belajar PAI dipengaruhi oleh variabel lain yang tidak dimasukkan dalam model penelitian. 
Dengan demikian hipotesis ketiga yang menyatakan "Virtual Learning PJJ GPAI, Partisipasi Orang Tua secara bersama-sama berpengaruh positif terhadap Hasil Belajar PAI Siswa SMP Negeri 4 Karanganyar tahun 2020/2021" diterima.

Pada tabel 17 menunjukkan besarnya sumbangan efektif variabel Virtual Learning PJJ GPAI sebesar 9,3\%. Artinya bahwa besarnya kontribusi variabel Virtual Learning PJJ GPAI terhadap hasil belajar PAI sebesar 9,3\% dan besarnya sumbangan relatif sebesar $27,5 \%$.

Pada tabel 17 menunjukkan besarnya sumbangan efektif variabel Patisipasi Orang Tua sebesar 10,5\%. Artinya bahwa besarnya kontribusi variabel Patisipasi Orang Tua terhadap Hasil Belajar PAI sebesar 10,5\% dan besarnya sumbangan relatif sebesar $31,1 \%$.

Hal ini berarti bahwa variabel Virtual Learning PJJ GPAI lebih dominan dan berpengaruh terhadap Hasil Belajar PAI. Berdasarkan tabel tersebut juga dapat disimpulkan bahwa secara bersama-sama variabel Virtual Learning PJJ GPAI, dan Partisipasi Orang Tua secara bersamasama memberikan sumbangan efektif sebesar 33,7\% terhadap Hasil Belajar PAI dan 66,3\% diberikan oleh variabel-variabel lain yang tidak dibahas dalam penelitian ini.

\section{KESIMPULAN}

Dengan adanya Virtual Learning PJJ GPAI yang baik, setiap individu mampu menhasilkan nilai yang baik. Pembelajaran yang disampaikan oleh guru mampu memberi pemahaman kepada peserta didik.

Peserta didik semakin giat dalam mengikuti virtual learning apabila seorang guru dalam menyampaikan materi dengan banyak inovasi dan memilih media yang sesuai. Seorang guru juga dituntut untuk lebih giat lagi dalam melakukan inovasi dan kreatifitas sehingga pembelajaran dapat diterima oleh peserta didik serta tidak membosankan.

Virtual Learning PJJ GPAI yang ditandai dengan ketercapaian kompetensi kelulusan yang diharapkan. Peserta didik mampu menyerap materi PAI dan dapat mengaplikasikan dalam kehidupan sehari-hari. Penilaian afektif, kognitif dan psikomotor dapat tercapai dengan memuaskan. Ketercapaian virtual learnimg yang dilakukan oleh guru akan menghasilkan peserta didik menjadi insan yang berakhlakul karima.

Partisipasi orang tua dalam Virtual learning sangatlah berpengaruh pada keberhasilan anak. Semakin orang tua ikut dalam memantau pembelajaran anak yang dilaksanakan dirumah maka anakpun semakin bersemangat. Apabila orang tua tidak memperhatikan maka anakpun tidak termotivasi 
mengikuti virtual learning. Orang tua diharapkan mampu menjadi guru dirumah, tempat bertanya bagi anak, memberikan bimbingan, penjelasan dan motivasi bagi anak.

Orang tua juga diharapkan bias memberikan pelayanan dan fasilitas pembelajaran bagi anaknya, karena dalam virtual learning dibutuhkan pula media dan aplikasi yang berhubungan dengan jaringan internet. Alat komunikasi hape, video, televisi maupun radio ikut menunjang dalam pembelajaran ini.

Patisipasi Orang Tua ditandai oleh beberapa hal yaitu kemampuan memecahkan masalah, intelegensi verbal, dan intelegensi praktis. Seorang anak akan lebih tenang dan mandiri ketika orang tua mampu mengarahkan dan menjadi teladan bagi anaknya. Dengan kemandirian anak inilah yang akan menjadikan anak lebih mapan dalam belajar. Dari uraian tersebut dapat disimpulkan bahwa Patisipasi Orang Tuamemiliki hubungan dengan Hasil Belajar PAI.

Hasil penelitian bahwa variabel Virtual Learning PJJ GPAI, dan Partisipasi Orang Tua berpengaruh positif secara bersama-sama terhadap Hasil Belajar PAI. Hal ini ditunjukkan oleh nilai F hitung sebesar 20,619 dan $\mathrm{p}$ value sebesar 0,000 .

Virtual Learning PJJ GPAI, dan Partisipasi Orang Tua berpengaruh terhadap Perilaku Etis memiliki kadar yang berbeda. Virtual Learning PJJ GPAI memiliki peran yang jauh lebih penting dibandingkan dengan Patisipasi Orang Tua.

Didapatkan hanya berpengaruh kira-kira 1,3\% bagi faktor-faktor yang menentukan keberhasilan siswa, sedangkan yang 98,7\% diisi dan dipengaruhi oleh kekuatan-kekuatan lain. Diantaranya ; sumber belajar yang memadai, sarana prasarana, komunikasi antara peserta didik dan guru, lingkungan yang mendukung, motivasi dan kesungguhan belajar peserta didik. 


\section{E. REFERENSI}

Dwiningrum, S. I. A. (2011). Desentralisasi dan partisipasi masyarakat dalam pendidikan. Pustaka Pelajar.

Hamalik, P. D. O. (2013). Proses belajar mengajar (Cet.6). Remaja rosda karya.

Ibrahim, N. (2005). ICT untuk Pendidikan Jarak Jauh. Jurnal Teknodik, 0 , 005-018. https://doi.org/10.32550/teknodik.v0i0.534

Maunah, B. (2016). Dampak Regulasi di Bidang TIK terhadap Perubahan Perilaku Sosial Siswa di Sekolah. Cakrawala Pendidikan, 35(2), Article 2. https://doi.org/10.21831/cp.v15i2.8953

Sofyana, L., \& Rozaq, A. (2019). Pembelajaran Daring Kombinasi Berbasis Whatsapp Pada Kelas Karyawan Prodi Teknik Informatika Universitas PGRI Madiun. Jurnal Nasional Pendidikan Teknik Informatika: JANAPATI, 8(1), 81-86. https://doi.org/10.23887/janapati.v8i1.17204

Somawati, A. V., Adnyana, K. S., Darmawan, I. P. A., Dewi, N. P. D. U., Untara, I. M. G. S., Suadnyana, I. B. P. E., Paramita, I. B. G., Wibawa, G. Y. S., Gunawijaya, I. W. T., Srilaksmi, N. K. T., \& Indrayasa, K. B. (2020). Bali vs COVID-19: Book Chapters. Nilacakra.

Sudjana, N. (1996). CBS A Cara belajar siswa aktif dalam proses belajar mengajar. Sinar Baru Algensindo.

Sutomo. (2021, Juni 21). Wawancara Kepala Sekolah SMP Negeri 4 Karanganyar kabupaten Karanganyar [Komunikasi pribadi].

Tim Sinar Grafika. (2008). Undang-undang Sisdiknas. Sinar Grafika. 